\title{
Extracellular enzyme activities in benthic cyanobacterial mats: comparison between nutrient- enriched and control sites in marshes of northern Belize
}

\author{
Dagmara Sirová $^{1, *}$, Jaroslav Vrba $^{1,2}$, Eliška Rejmánková ${ }^{3}$ \\ ${ }^{1}$ University of South Bohemia, Faculty of Biology, Department of Ecology, Branišovská 38, České Budějovice 37005 , \\ Czech Republic \\ ${ }^{2}$ Biology Centre AS CR, Institute of Hydrology, Na Sádkách 7, České Budějovice 370 05, Czech Republic \\ ${ }^{3}$ Department of Environmental Science and Policy, University of California Davis, One Shields Avenue, Davis 95616 , \\ California, USA
}

\begin{abstract}
Cyanobacterial mats, an important component of the oligotrophic alkaline wetland ecosystems of the Caribbean, are sensitive to nutrient enrichment. In order to elucidate their role in nutrient cycling, we measured extracellular enzyme activities in cyanobacterial mats and underlying sediment exposed to a long-term effect of different salinities and nutrient enrichment. Activities of alkaline phosphatase, leucine-aminopeptidase, arylsulphatase, and $\beta$-glucosidase were measured fluorometrically. The distribution of phosphatase activity among different groups of microorganisms in the vertical structure of the mat was visualized using ELF ${ }^{\circledR} 97$ phosphate. The activity of all enzymes, except arylsulphatase, was localized mainly in the mat itself and was several times higher than in the underlying sediment. Phosphatase always exhibited the highest activity, followed by leucine-aminopeptidase, arylsulphatase and $\beta$-glucosidase. Phosphatase activity was significantly suppressed in P-addition plots under all salinity levels. The remaining enzymes were not significantly influenced by nutrient addition. Cyanobacteria, which formed most of the mat biomass, exhibited no phosphatase activity, with the exception of Chroococcus spp. Hence, we presume that the main sources of extracellular enzymes are different species of bacteria distributed in the mat and the mucilaginous sheaths of cyanobacteria. Sediment type, rather than salinity, seems to have an important influence on the extracellular enzyme production strategies.
\end{abstract}

KEY WORDS: Alkaline phosphatase $\cdot$ Leucine-aminopeptidase $\cdot \beta$-glucosidase $\cdot$ Arylsulphatase · Extracellular polymeric substances $\cdot$ Phosphorus

Resale or republication not permitted without written consent of the publisher

\section{INTRODUCTION}

Cyanobacterial mats are benthic microbial communities in which cyanobacteria are the main matbuilding group (Jørgensen et al. 1983). In these complex ecosystems a variety of different functional groups of organisms forms a structural and physiological unit (Stal 2001). Cyanobacterial mats are found in extreme environments throughout the world: in lagoons and estuaries (Western Australia, Baja California, Persian
Gulf), hot springs (Yellowstone National Park), in shallow lakes (Ethiopia) and alkaline wetlands (Florida Everglades, Cuba, Yucatan peninsula) (Castenholz 1973, Brock 1978, Jørgensen et al. 1983, Komárek 1989, 1995). Mats tend to develop in sufficiently hostile environmental conditions, where the growth and survival of benthic meio- and macrofauna, and hence grazing and bioturbations, are prevented (Jørgensen et al. 1983).

Limestone-based wetlands covering extensive areas of the Yucatan peninsula, where our study site is 
located, are characterized by rather extreme conditions in terms of hydrology, nutrient availability and salinity (Rejmánková et al. 1996). These harsh conditions allow the development of thick cyanobacterial mats, harboring great diversity of cyanobacterial species (Rejmánková et al. 2004). Mats are an important component of northern Belizean marshes, constituting a major part of biomass and primary production coupled with both nitrogen fixation and production of large amounts of polysaccharide-rich extracellular polymeric substances (EPS). The production of EPS may be an important direct source of carbon for associated communities of heterotrophic bacteria (Bell et al. 1983, Espeland et al. 2001), while the nitrogen fixed in mats is utilized by non nitrogen-fixing bacteria and macrophytes (Rejmánková \& Komárková 2000). Cyanobacterial mats also influence sediment formation in these systems in that large amounts of calcium carbonate are precipitated during photosynthesis forming marl deposits.

Little is known about the role of cyanobacterial mats in nutrient cycling. This has become an increasingly important question as these unique wetlands are threatened by accelerated land use and a consequent increase in nutrient loading (King et al. 1992). The resulting process of eutrophication is known to cause changes in primary functions of tropical ecosystems worldwide (Downing et al. 1999).

One of the crucial ecosystem processes susceptible to alteration by increased nutrient input is the hydrolysis of organic macromolecular compounds. Organic polymers exist in aquatic environments mostly as dissolved organic matter (DOM) and particulate organic matter (POM) (Thurman 1985, Alvarez \& Guerrero 2000). The process of DOM and POM hydrolysis is mediated by extracellular enzymes, which break down high molecular weight compounds into smaller molecules available for uptake by cells (Chróst 1990). Extracellular enzymes are produced by a variety of organisms, but the majority of their activity seems to be derived from microbial processes (Štrojsová et al. 2003). These processes are crucial in the remineralization of nutrients and primary production; therefore, studying extracellular enzyme activities and distribution may provide important information about the cycling of nutrients in ecosystems.

While techniques were developed to measure extracellular enzyme activities (Hoppe 1983), the problem of determining which organisms are producing the activity remains (Vaitomaa et al. 2002). Few studies have tried to determine the ecological role of cyanobacterial enzymes (Vaitomaa et al. 2002, Štrojsová et al. 2003). One of the reasons for this may be that cyanobacterial surfaces are often colonized by bacteria (Paerl 1982) and it is difficult to distinguish between the 2 enzyme sources.

Different organisms use different strategies concerning extracellular enzyme production and these are greatly influenced by the physical and chemical characteristics of the environment as well as by the physiological state of the cells. The enzyme is either bound to the cell membrane or released into the environment surrounding the cell. It seems that dissolved enzymes are more prone to degradation, for example, by bacterial proteases. Surface-bound enzymes, on the other hand, exhibit problems associated with reduced diffusibility of substrate (Wetzel 1991).

In this study we examined the activities of 4 extracellular enzymes: alkaline phosphatase, leucine-aminopeptidase, $\beta$-glucosidase and arylsulphatase. These enzymes play crucial roles in the cycling of phosphorus, nitrogen, carbon and sulphur respectively (Sinsabaugh \& Linkins 1988). We aimed to determine the influence of nutrient addition, salinity and desiccation on the activity of these enzymes, and to assess their distribution between the cyanobacterial mat and the underlying sediment. Alkaline phosphatase seems to play an important role in these extremely phosphorusdeficient systems (Rejmánková and Komárková 2000). A more detailed study, using enzyme-labeled fluorescence, focused on selected samples from 2 locations differing in sediment type to visualize the distribution of phosphatase activity among various organisms living within the cyanobacterial mat.

\section{MATERIALS AND METHODS}

Study site. Inland wetlands in limestone-based tropical regions of the Yucatan peninsula, such as those in northern Belize, are characterized by rather extreme conditions in terms of hydrology, nutrient availability and salinity (Rejmánková et al. 1996). These wetlands range in size from small $<1$ ha marshes to large shallow inland lagoons $\left(>100 \mathrm{~km}^{2}\right)$. The climate of the Yucatan peninsula is tropical wet-dry, with predictable temperature regime and unpredictable rain patterns (Hartshorn 1988). Hydrology is driven mainly by precipitation and evapotranspiration. The mean annual rainfall in northern Belize is 1300 to $1500 \mathrm{~mm}$ but varies substantially from year to year (King et al. 1992). Most wetlands in the study area remain flooded or water saturated throughout the year. The range of mean annual minimum and maximum temperatures is 22.8 to $30.2^{\circ} \mathrm{C}$ (Belize Department of Meteorology unpubl. data).

Essentially all of these wetlands consist of either monodominant stands or mixtures dominated by the following macrophyte species: Eleocharis cel- 
lulosa, E. interstincta, Cladium jamaicense and Typha domingensis (Rejmánková et al. 1995, 1996). Frequent co-dominants are submersed species of the genera Utricularia and Chara and floating-leaved Nymphaea ampla.

Important components of these shallow marsh systems are microbial mats consisting of fine filaments of Leptolyngbya spp. (Cyanobacteria) forming most of the mat biomass, intermingled with many other species of cyanobacteria (Rejmánková et al. 2004, Rejmánková \& Komárková 2000), and heterotrophic and photoheterotrophic bacteria (D. Sirová pers. obs.).

Nine locations representing the range of size, water depth, water chemistry, and macrophyte density occurring in marshes of northern Belize were selected for sampling (Fig. 1). Characteristics of each location are summarized in Table 1.

On each location, a long-term nutrient addition experiment was set up in July 2001. Four plots $(10 \times$ $10 \mathrm{~m}$ ) were designated at each marsh, one served as a control (C), one received phosphorus (P) addition $\left(10 \mathrm{~g} \mathrm{P} \mathrm{m}^{-2}\right)$, one received nitrogen $(\mathrm{N})$ addition $(20 \mathrm{~g} \mathrm{~N}$ $\mathrm{m}^{-2}$ ) and to the fourth plot (NP) a combination of both nutrients was added in the same amounts approximately every 12 mo. Sampling was done in January 2004, 17 mo after the last nutrient addition.

Sampling. To localize extracellular enzymatic activity, samples were collected from benthic cyanobacterial mats, 2 layers of the underlying sediment and the water column. In $\mathrm{P}$ and NP plots, which lacked cyanobacterial mats, only the sediment was sampled. Corers $3 \mathrm{~cm}$ in diameter were used to obtain the ben-

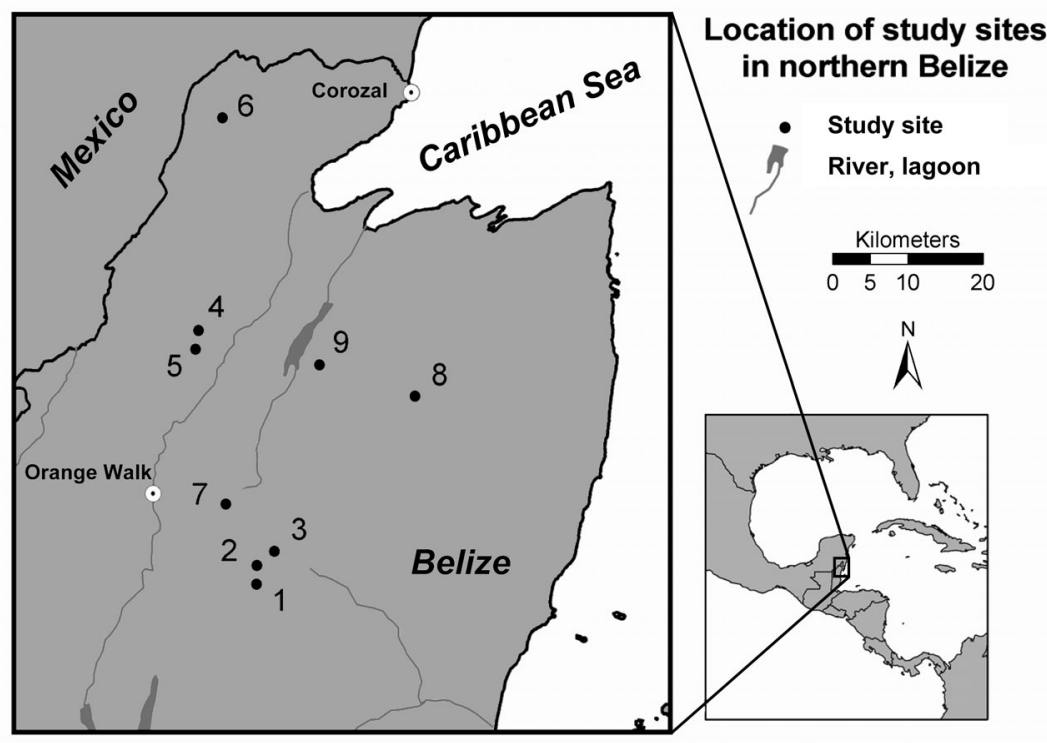

Fig. 1. Study sites in northern Belize. Low salinity locations: (1) Frank, (2) Deep, (3) Hidden. Medium salinity locations: (4) BV, (5) New, (6) Eli's. High salinity locations: (7) Doubloon, (8) LB 7, (9) LB 11 thic samples. Cores were divided into separate samples: cyanobacterial mat, upper and lower $2.5 \mathrm{~cm}$ thick sediment layers. For detailed description of sediment characteristics of the study sites see Kim \& Rejmánková (2002).

Pooled samples ( 5 replicates of each of the 3 different layers from every plot and location) were made for the bulk enzyme assay and refrigerated prior to laboratory analysis. Samples for the visualization of phosphatase activity were frozen at $-20^{\circ} \mathrm{C}$ until analysis. Selected plots and locations were sampled for bacterial counts. These samples were preserved in $3 \%$ formaldehyde.

To determine the effect of desiccation on the activity of alkaline phosphatase, samples were collected in August 2004 at 3 locations representing the low (Frank), medium (Eli's) and high (Doubloon) salinity marshes. A drying gradient formed at these locations during a prolonged period of drought. We designated 3 points along this gradient: dry (mat completely sundried for a period of $10 \mathrm{wk}$ ), damp (mat damp, but not submerged) and wet (mat submerged, water level at least $30 \mathrm{~cm}$ above the surface of the mat). Samples were collected from cyanobacterial mat and 2, $2.5 \mathrm{~cm}$ thick underlying sediment layers in 5 replicates, from control plots only.

Enzyme assay. Extracellular enzyme activities were determined using MUF (4-methyl-umbelliferyl) substrate analogues (Sigma) for the measurement of phosphatase, $\alpha$-glucosidase and arylsulphatase; leucineAMC (L-leucine-7-amido-4-methyl-coumarin) (Sigma) was used for measurements of leucine-amidopeptidase activity (Hoppe 1993). From each sample, $3 \mathrm{~g}$ were homogenized in $60 \mathrm{ml}$ of TRIS buffer $(\mathrm{pH} 8.0) ; 200 \mu \mathrm{l}$ of the homogenate was pipetted into a microplate well in 4 replicates. A total of $50 \mu \mathrm{l}$ of substrate were added to each replicate prior to fluorescence reading. The final concentration of substrates used was $1 \mathrm{mM}$ for phosphatase and, $\beta$ glucosidase assays, and $0.5 \mathrm{mM}$ for arylsulphatase and leucine-aminopeptidase. A portion of the homogenized sample was treated with $\mathrm{HgCl}_{2}(4 \mathrm{mM}$ $\mathrm{l}^{-1}$ final concentration), which served as a fixative stopping all enzymatic activity, and used as blank in 3 replicates to determine non-enzymatic hydrolysis of the substrates. MUF and AMC dissolved in the sample homogenate were used as standards and standard curves were used to calculate enzyme activity. Fluorescence was measured every 5 min for 20 min (phosphatase and arylsulphatase), $30 \mathrm{~min}$ ( $\beta$-glucosidase) and 
Table 1. Environmental characteristics of the study sites. Values represent means from August 2001 and 2002 , February 2002 and 2003; SRP: soluble reactive phosphorus; Surf.: surface water, inter.: interstitial water (for methods see Rejmánková et al. 1996)

\begin{tabular}{|c|c|c|c|c|c|c|c|c|c|c|c|c|c|c|c|c|}
\hline \multirow[t]{2}{*}{ Marsch } & \multirow[t]{2}{*}{$\begin{array}{c}\text { Area } \\
\text { (ha) }\end{array}$} & \multirow[t]{2}{*}{$\begin{array}{l}\text { Sedi- } \\
\text { ment }\end{array}$} & \multicolumn{2}{|c|}{$\mathrm{pH}$} & \multicolumn{2}{|c|}{$\begin{array}{l}\text { Conductivity } \\
\left(\mu \mathrm{S} \mathrm{cm}^{-1}\right)\end{array}$} & \multicolumn{2}{|c|}{$\begin{array}{c}\text { SRP } \\
\left(\mu \mathrm{mol} \mathrm{l^{-1 } )}\right.\end{array}$} & \multicolumn{2}{|c|}{$\begin{array}{c}\mathrm{NH}_{4}-\mathrm{N} \\
\left(\mu \mathrm{mol} \mathrm{l}{ }^{-1}\right)\end{array}$} & \multicolumn{2}{|c|}{$\begin{array}{c}\mathrm{NH}_{3}-\mathrm{N} \\
\left(\mu \mathrm{mol} \mathrm{l} l^{-1}\right)\end{array}$} & \multicolumn{2}{|c|}{$\begin{array}{c}\mathrm{SO}_{4} \\
\left(\mathrm{mmol} \mathrm{l}^{-1}\right)\end{array}$} & \multicolumn{2}{|c|}{$\begin{array}{c}\mathrm{Cl} \\
\left(\mathrm{mmol} \mathrm{l}^{-1}\right)\end{array}$} \\
\hline & & & Surf & Inter & Surf & Inter & Surf & Inter & Surf & Inter & Surf & Inter & Surf & Inter & Surf & Inter \\
\hline \multicolumn{17}{|c|}{ Low salinity } \\
\hline Frank & 1.2 & Peat/clay & 7.7 & 6.8 & 230 & 310 & 0.31 & 0.53 & 3.05 & 58.26 & 1.60 & 2.12 & 0.03 & 0.21 & 0.11 & 0.21 \\
\hline Deep & 4.7 & Peat & 7.4 & 6.7 & 174 & 219 & 0.52 & 1.04 & 8.32 & 33.24 & 9.22 & 0.10 & 0.12 & 0.18 & 0.23 & 0.24 \\
\hline Hidden & 11.3 & Marl & 7.7 & 7.0 & 257 & 638 & 0.53 & 0.63 & 8.57 & 145.38 & 1.46 & 0.10 & 0.03 & 0.03 & 0.17 & 0.77 \\
\hline \multicolumn{17}{|c|}{ Medium salinity } \\
\hline $\mathrm{BV}$ & $83.7^{1}$ & Clay & 7.9 & 7.0 & 904 & 1304 & 0.48 & 0.43 & 5.04 & 45.13 & 0.52 & 0.16 & 4.34 & 2.25 & 2.19 & 4.51 \\
\hline New & 78.9 & Clay & 7.8 & 7.0 & 1708 & 2628 & 0.33 & 0.39 & 6.39 & 27.56 & 3.57 & 0.00 & 18.15 & 46.50 & 7.69 & 12.04 \\
\hline Eli's & 16.8 & Clay & 7.8 & 7.1 & 963 & 1283 & 0.42 & 0.44 & 4.61 & 77.02 & 1.66 & 0.02 & 1.50 & 6.30 & 2.86 & 3.02 \\
\hline \multicolumn{17}{|c|}{ High salinity } \\
\hline Doubloon & 63.4 & Marl & 8.0 & 7.0 & 4736 & 6158 & 0.50 & 1.15 & 3.39 & 81.39 & 4.76 & 1.24 & 26.40 & 39.88 & 27.69 & 40.63 \\
\hline LB 7 & 18.2 & Marl & 8.0 & 7.0 & 4414 & 5483 & 0.37 & 0.72 & 3.39 & 121.14 & 1.56 & 0.00 & 1.26 & 19.26 & 2.68 & 50.07 \\
\hline LB 11 & 66.7 & Marl & 7.8 & 7.0 & 4372 & 6608 & 0.40 & 1.75 & 13.46 & 318.15 & 3.52 & 1.17 & 3.03 & 15.60 & 8.68 & 25.14 \\
\hline
\end{tabular}

$50 \mathrm{~min}$ (leucine-aminopeptidase) at $30^{\circ} \mathrm{C}$ with $355 \mathrm{~nm}$ excitation and $445 \mathrm{~nm}$ emission filters. Fluorcam microplate reader was used. The enzyme activity was expressed per unit ash free dry weight (AFDW), as samples from different locations differ considerably in ash content.

Phosphatase visualization. The extracellular activity of phosphatase was visualized using artificial ELF ${ }^{\circledR} 97$ phosphate (ELFP) from the Endogenous Phosphatase Detection Kit (Molecular Probes) which forms insoluble fluorescent precipitates of ELF-alcohol (ELFA) at the site of enzymatic activity. Mat cores were homogenized and treated with $3 \%$ acetic acid for $10 \mathrm{~min}$ to dissolve crystals of calcium carbonate. Cores containing both mat and sediment used for the enumeration of active enzyme sites (a single ELFA precipitate was counted as 1 active enzyme site) as well as bacteria were sectioned into $11 \mathrm{~mm}$ thick layers, which were consequently homogenized. ELFP was diluted 40 times with detection buffer, filtered using $0.2 \mu \mathrm{m}$ membrane filter and $4 \mu \mathrm{l}$ of the filtered solution was added to $50 \mu \mathrm{l}$ of homogenized sample on the microscope slide. The sample was incubated in the dark at room temperature for $15 \mathrm{~min}$ and examined for the presence of ELFA precipitates with an epifluorescence microscope (Olympus AX-70) using the UV-excitation filter set with a long pass emission filter (excitation/emission: 360 to 370 $\mathrm{nm} / 420 \mathrm{~nm}$ ) (Nedoma et al. 2003). Both green ELFA fluorescence and red chlorophyll a autofluorescence were visible using this filter set. Fixed samples used for bacterial enumeration were filtered, treated with DAPI stain (Porter \& Feig 1980) and filters were evaluated under the epifluorescence microscope.

Other methods. All samples were analyzed for total $\mathrm{N}$ and $\mathrm{C}$ on the Carlo-Erba series $5000 \mathrm{CHNS}$ analyzer.
Total P was measured spectrophotometrically after combustion and consequent acid digestion (McNamara \& Hill 2000). Carbonates were analyzed gravimetrically using consequent combustion at 105, 550 and $800^{\circ} \mathrm{C}$. Data were analyzed using Generalised Linear Model method in the STATISTICA v6.0 program (StatSoft).

\section{RESULTS}

Of the 9 study sites, those in high salinity group were characterized by marl sediments, medium salinity sites were clay-based, and low salinity marshes generally had peat or peaty-clay sediments (Table 1).

\section{Extracellular enzyme activity and distribution}

Fluorometric measurements showed that alkaline phosphatase exhibited the highest activity of the 4 enzymes studied, followed by leucine-aminopeptidase, arylsulphatase, and $\beta$-glucosidase (Fig. 2). Salinity had no significant effect on the activity of these enzymes, except for leucine-aminopeptidase, which showed significantly higher activities at high salinity locations (Table 2).

The activity of phosphatase, leucine-aminopeptidase and $\beta$-glucosidase was localized mainly in the cyanobacterial mat itself, being several orders of magnitude higher than in the underlying sediment (Fig. 2A-C). The activity of arylsulphatase was distributed more evenly among the different layers and it was the only enzyme whose activity increased with depth, reaching maximum values at layers of sediment 2.5 to $5 \mathrm{~cm}$ deep (Fig. 2D). 

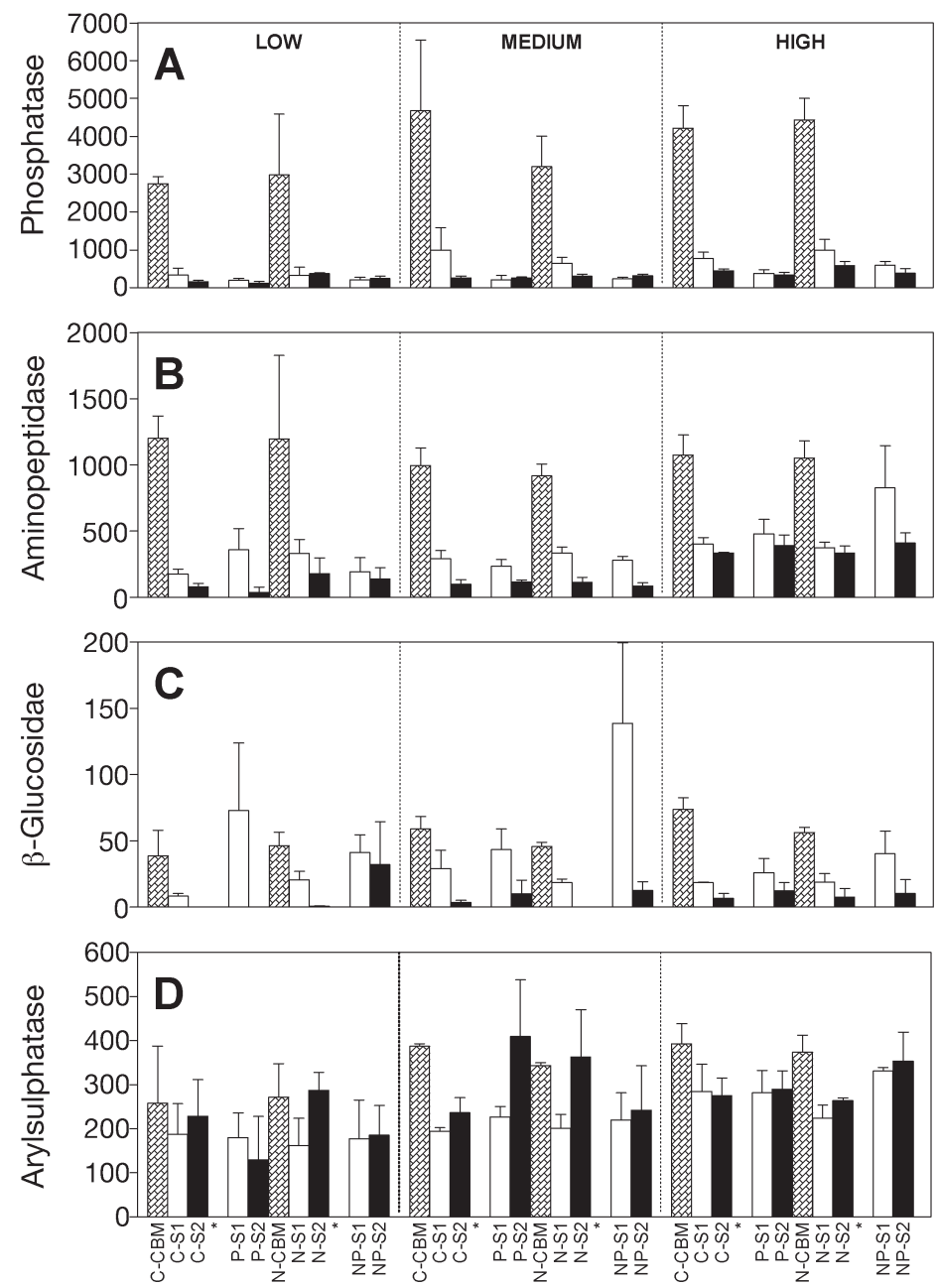

Fig. 2. Extracellular enzyme activities of (A) phosphatase, (B) aminopeptidase, (C) $\beta$-glucosidase, and (D) arylsulpatase, expressed as $\mu \mathrm{mol}(\mathrm{g} \text { AFDW })^{-1} \mathrm{~min}^{-1}$ (mean + SE) in the cyanobacterial mat (CBM), the first (S1) and second (S2) layer of the underlying sediment from the control (C), phosphorus $(\mathrm{P})$, nitrogen $(\mathrm{N})$ and combined (NP) treatments. Samples of CBM missing due to macrophyte shading are omitted (*)

Phosphorus addition led to a rapid increase in density of the macrophyte Eleocharis cellulosa and E. interstincta and resulting shading caused the disappearance of cyanobacterial mats in $\mathrm{P}$ and NP plots in all locations. This layer was therefore excluded from hierarchical statistical analyses (Table 2).

Alkaline phosphatase activity in the sediment decreased significantly at P plots under all salinity levels. The relationship between total phosphorus content and alkaline phosphatase activity is shown in Fig. 3. The highest activities were observed in the total phosphorus concentration range of 100 to $500 \mu \mathrm{g} \mathrm{l}^{-1}$ with a sharp threshold at $500 \mu \mathrm{g} \mathrm{l}^{-1}$. The other enzymes under study did not respond significantly to $\mathrm{P}$ addition
(Table 2). $\beta$-glucosidase showed a slight tendency towards higher activities in the P plots. Nitrogen had no significant impact on the activity of the studied enzymes (Table 2).

\section{Effect of dessication on phosphatase activity}

At low and high salinity locations, the damp mat retained all of the alkaline phosphatase activity present in mats that were submersed completely. The activity decreased by approximately one-half in the damp mats at medium salinity location. Dry mats at all 3 locations retained the same activity of 350 to $450 \mu \mathrm{mol} \mathrm{g}{ }^{-1}$ AFDW $\min ^{-1}$ after $10 \mathrm{wk}$ of desiccation (Fig. 4).

\section{Visualization of alkaline phosphatase activity distribution}

Observation of samples under the epifluorescence microscope revealed that alkaline phosphatase was mostly unassociated with cyanobacterial cells. The only exceptions were Chroococcus species consistently producing membrane-bound phosphatase activity throughout the samples and the occasional activity of other coccoidal cyanobacteria, mainly Aphanothece sp. (Fig. 5) Filamentous species such as the most abundant Leptolyngbya were not active under study conditions (Fig. 6).

Detailed analysis was performed on samples from 2 locations differing considerably in salinity and sedi-

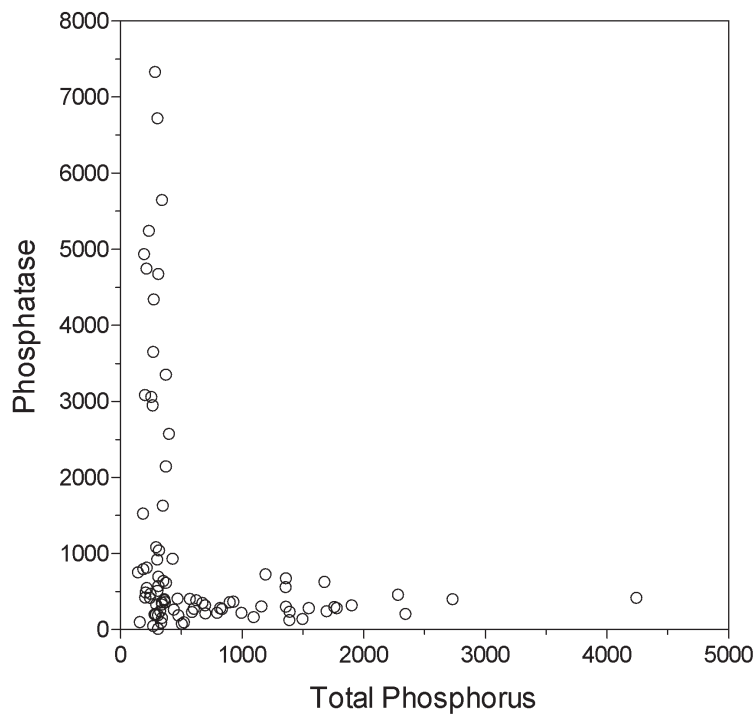

Fig. 3. Relationship between mean alkaline phosphatase activity in $\mu \mathrm{mol}\left(\mathrm{g}^{-1}\right.$ AFDW) $\mathrm{min}^{-1}$ and total phosphorus content in $\mu \mathrm{g}\left(\mathrm{g}^{-1}\right.$ AFDW) in the cyanobacterial mat in all layers 
Table 2. Results of the Generalised Linear Model test comparing the effect of salinity, layer, $\mathrm{N}$ and $\mathrm{P}$ on the activity of the 4 enzymes at the 9 locations and 4 plots

\begin{tabular}{|c|c|c|c|c|c|c|}
\hline Factor & df effect & MS effect & df error & MS error & $F$ & $\mathrm{p}$ \\
\hline \multicolumn{7}{|c|}{ Phosphatase } \\
\hline Salinity & 2 & 466707.4 & 6 & 153908.0 & 3.032 & 0.1230 \\
\hline Layer & 1 & 521390.7 & 51 & 66587.9 & 7.83 & 0.0072 \\
\hline $\mathrm{N}$ & 1 & 93355.2 & 51 & 66587.9 & 1.402 & 0.2419 \\
\hline $\mathrm{P}$ & 1 & 918464.2 & 51 & 66587.9 & 13.793 & 0.0005 \\
\hline \multicolumn{7}{|c|}{ L-aminopeptidase } \\
\hline Salinity & 2 & 514901.8 & 5.14 & 82462.5 & 6.244 & 0.0421 \\
\hline Layer & 1 & 481458.5 & 51 & 23133.7 & 20.812 & $<0.0001$ \\
\hline $\mathrm{N}$ & 1 & 45245.3 & 51 & 23133.7 & 1.956 & 0.1680 \\
\hline $\mathrm{P}$ & 1 & 32347.0 & 51 & 23133.7 & 1.4 & 0.2425 \\
\hline \multicolumn{7}{|c|}{ Arylsulphatase } \\
\hline Salinity & 2 & 58961.1 & 3.1 & 53460.7 & 1.103 & 0.3959 \\
\hline Layer & 1 & 44163.9 & 51 & 8767.9 & 5.037 & 0.0292 \\
\hline $\mathrm{N}$ & 1 & 917.3 & 51 & 8767.9 & 0.105 & 0.7477 \\
\hline $\mathrm{P}$ & 1 & 1738.5 & 51 & 8767.9 & 0.198 & 0.6580 \\
\hline \multicolumn{7}{|c|}{$\beta$-glucosidase } \\
\hline Salinity & 2 & 16925.7 & 5.47 & 8491.9 & 1.993 & 0.2776 \\
\hline Layer & 1 & 53682.7 & 51 & 11444.4 & 4.691 & 0.0350 \\
\hline $\mathrm{N}$ & 1 & 42476.4 & 51 & 11444.4 & 3.712 & 0.0596 \\
\hline $\mathrm{P}$ & 1 & 18521.7 & 51 & 11444.4 & 1.618 & 0.2091 \\
\hline
\end{tabular}

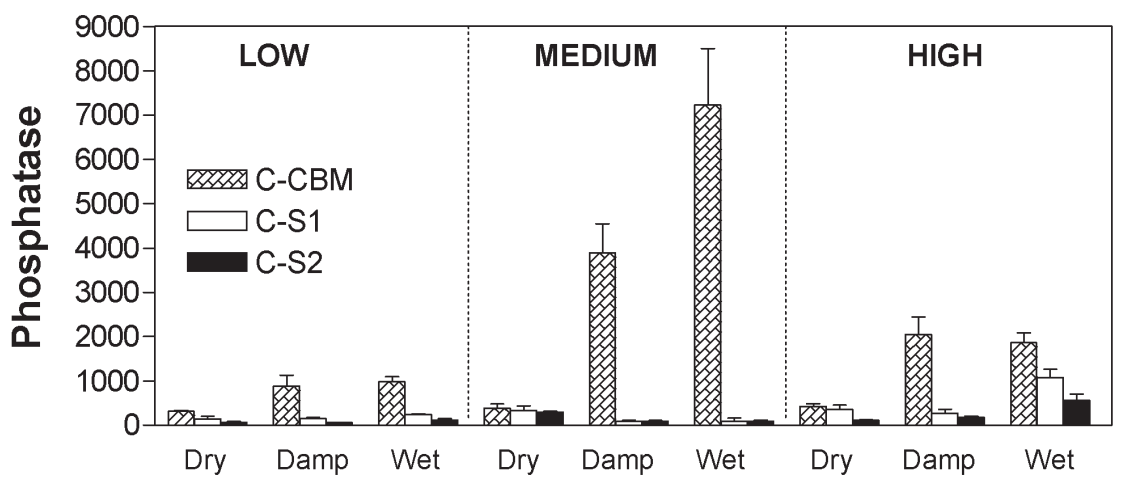

Fig. 4. Alkaline phosphatase activity expressed as $\mu \mathrm{mol}\left(\mathrm{g}^{-1}\right.$ AFDW) $\mathrm{min}^{-1}$ (mean + SE) in dry, damp and wet samples, from the control and the plot cyanobacterial mat (CBM), first (S1) and second (S2) sediment layer for low, medium and high salinity locations

ment type. Sediment at the high salinity marl-based mangrove location LB11 contained 30\% more carbonates than peat-based sediment at the low salinity location Frank. Bacterial enumeration using DAPI staining showed no significant differences between the 11, $1.5 \mathrm{~mm}$ thick layers of mat and sediment on either location (Fig. 7).

Active enzymes sites were distributed in the mucilaginous cyanobacterial sheaths and EPS matrix throughout the mat (Fig. 6); highest activity was observed in the lower layers at the transitional zone between the mat and the underlying sediment. At both locations, most of the phosphatase activity in the cyanobacterial mats appeared free, unassociated with bacterial cells (Fig. 6).

There were considerable differences in the distribution of active enzyme sites between the 2 sediment types. Most of the phosphatase activity in the marl-based sediment appeared to be free activity. Peat-based sediment supported microbial community with phosphatase activity mostly bound to the surface of cells and the proportion of bound active enzyme sites increased with depth into the sediment (Fig. 6). The activity of alkaline phosphatase derived from active enzyme site counts was an order of magnitude higher in the high-salinity location.

\section{DISCUSSION}

In this study we measured and localized the activity of 4 extracellular enzymes in the cyanobacterial mats and the underlying sediment in alkaline wetlands of northern Belize and assessed the influence of nutrient addition and salinity on their activity. To our knowledge this is the first detailed study of extracellular enzyme activity in benthic microbial mats and the first attempt to visualize alkaline phosphatase activity and distribution among different groups of organisms living within the mat.

The activity of the studied enzymes, with the exception of arylsulphatase, was several times higher in the cyanobacterial mat than in the underlying sediment in all sampled locations. This may be the result of extracellular enzyme accumulation in the EPS matrix of the mat. It has been suggested that the matrix promotes accumulation of the more freely deployed enzymes by retarding losses (Lock et al. 1984), and several possible mechanisms that could affect a net accumulation (physical enmeshment, hindered diffusion, adsorption or cation bridging) have been proposed by Characklis \& Marshall (1990).

The accumulation of enzymes in the EPS matrix is likely further promoted by the high metabolic activity of attached bacteria and tight internal nutrient cycling common in biofilm communities (Van Loodsdrecht et al. 1990). The advantage of accumulation is presum- 
Red channel
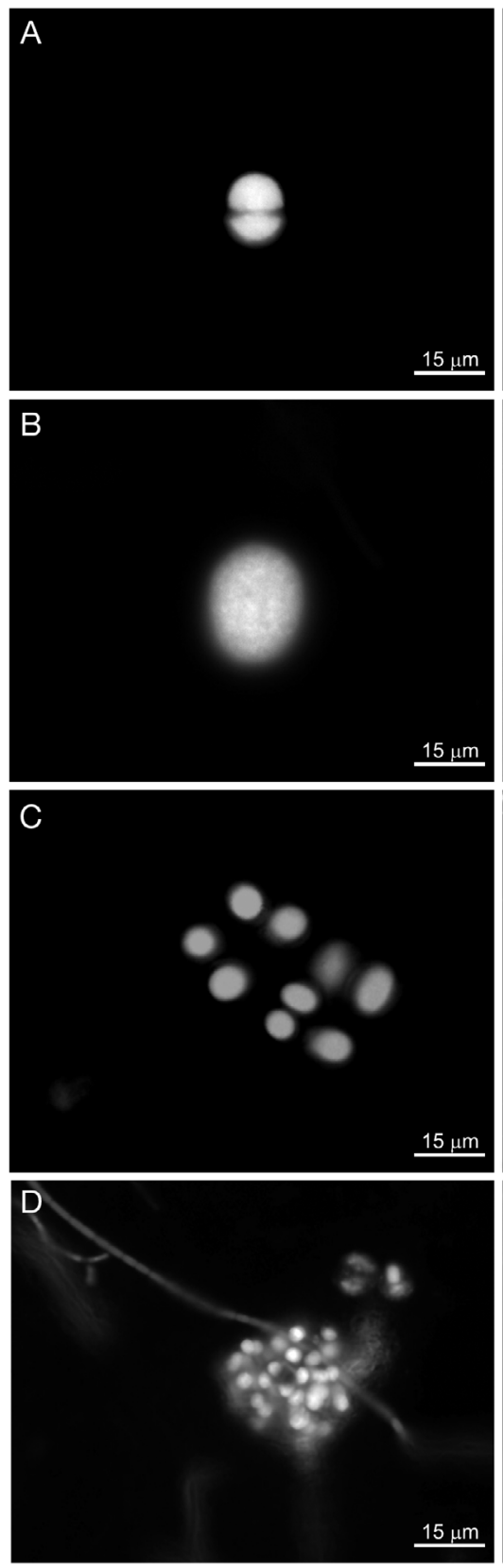

Fig. 5. Microphotographs of ELF-alcohol (ELFA)-labeled samples in both the red (chlorophyll autofluorescence) and green (ELFA fluorescence) channel. $(\mathrm{A}, \mathrm{B})$ Chroococcus sp. showing surface-bound activity. (C,D) Coccoidal cyanobacterial cells without phosphatase activity; active sites are distributed in the mucilaginous sheaths and the EPS matrix surrounding the cells
Green channel
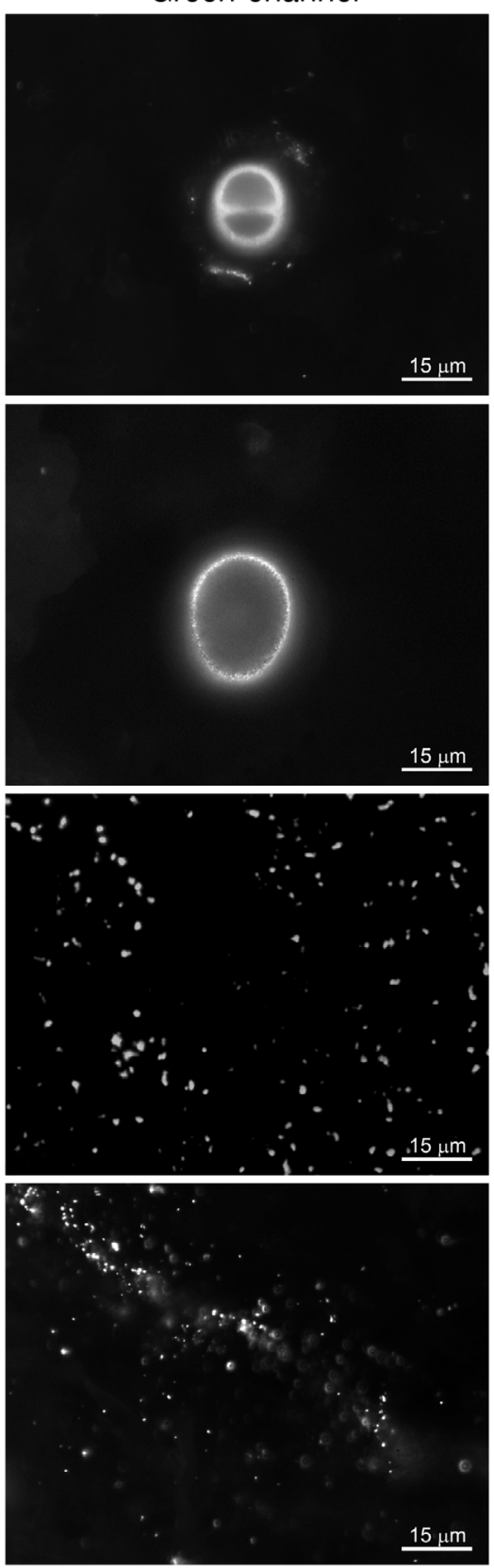

In biofilms, bacteria are in a close relationship with algae and rapidly utilize extracellular organic carbon (EOC) released from algal and cyanobacterial cells during active cell metabolism or following cell senescence (Espeland et al. 2001). It has been shown that increased light intensities, to which cyanobacterial mats studied are exposed, stimulate extracellular enzyme activity (Espeland \& Wetzel 2001a). Romaní \& Marxsen (2002) found higher enzymatic activities of stream biofilms in unshaded sites. Aminopeptidase activity was reported to be enhanced by the release of proteinaceous substances by living or senescent algal cells (Hoch et al. 1996), which is a process likely to occur within cyanobacterial mat communities. A positive relationship between chlorophyll $a$ and aminopeptidase activity in stream epilithic biofilms was observed by Ainsworth \& Goulder (2000).

The activity and persistence of extracellular enzymes is highly variable, influenced by many chemical and environmental factors (Espeland \& Wetzel 2001b). Enzymes are generally short-lived since they are susceptible to inactivation, often by photodegradation (Perez-Mateos et al. 1991). Mat EPS matrix may provide photochemical protection of enzymes located within it via attenuation of UV radiation (Elasri \& Miller 1999). Additionally enzymes located within the matrix may be further shielded by fluorochromes and the high amounts of the cyanobacterial sheath pigment scytonemin, which we found to be present throughout the mat (data not shown).

The protection of the EPS matrix seems indeed to be effective, as $25 \%$ of the activity on average was retained in mat samples that were completely sun-dried for $3 \mathrm{mo}$. It is possible that enzyme activity retained in dessicated

ably the diversion of resources from the synthesis of extracellular enzymes to microbial growth and this in turn may contribute to the high metabolic rates observed for attached microbiota. The disadvantage is a slower response of microbial community to changes in carbon resources (Sinsabaugh et al. 1991). samples contributes to the extremely high regeneration rates in these mats after flooding (data not shown).

Alkaline phosphatase exhibited the highest activity among enzymes studied at all locations. Its activity together with the activity of $\beta$-glucosidase and aminopeptidase decreased with increasing depth. 

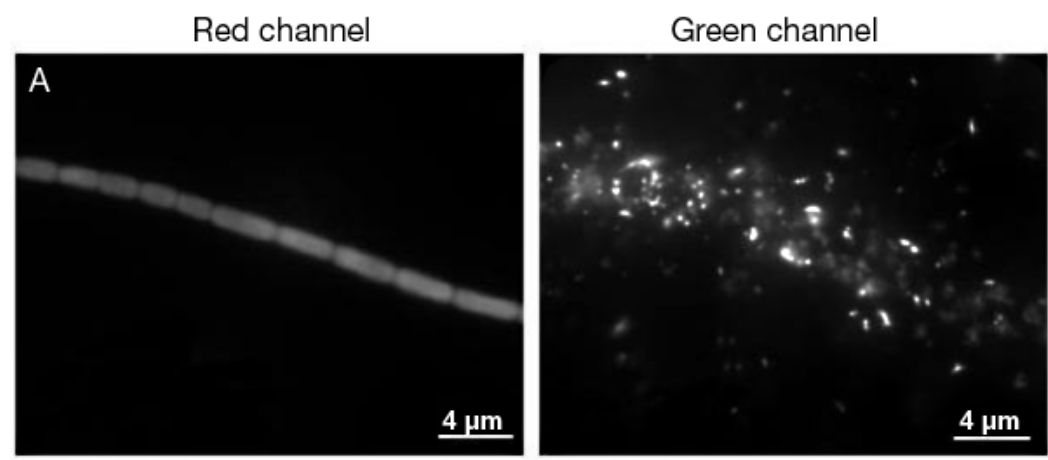

ther of the studied enzymes responded significantly to $\mathrm{N}$ enrichment.

Alkaline phosphatase activity in the cyanobacterial mat, visualized by ELFalcohol labeling and expressed as number of active sites $\mathrm{g}^{-1}$ AFDW, was mostly unassociated with cyanobacterial cells. Although some bacterial cells were labeled, most of the activity appeared free and was located in the EPS matrix throughout the mat, decoupled from its source in both space and
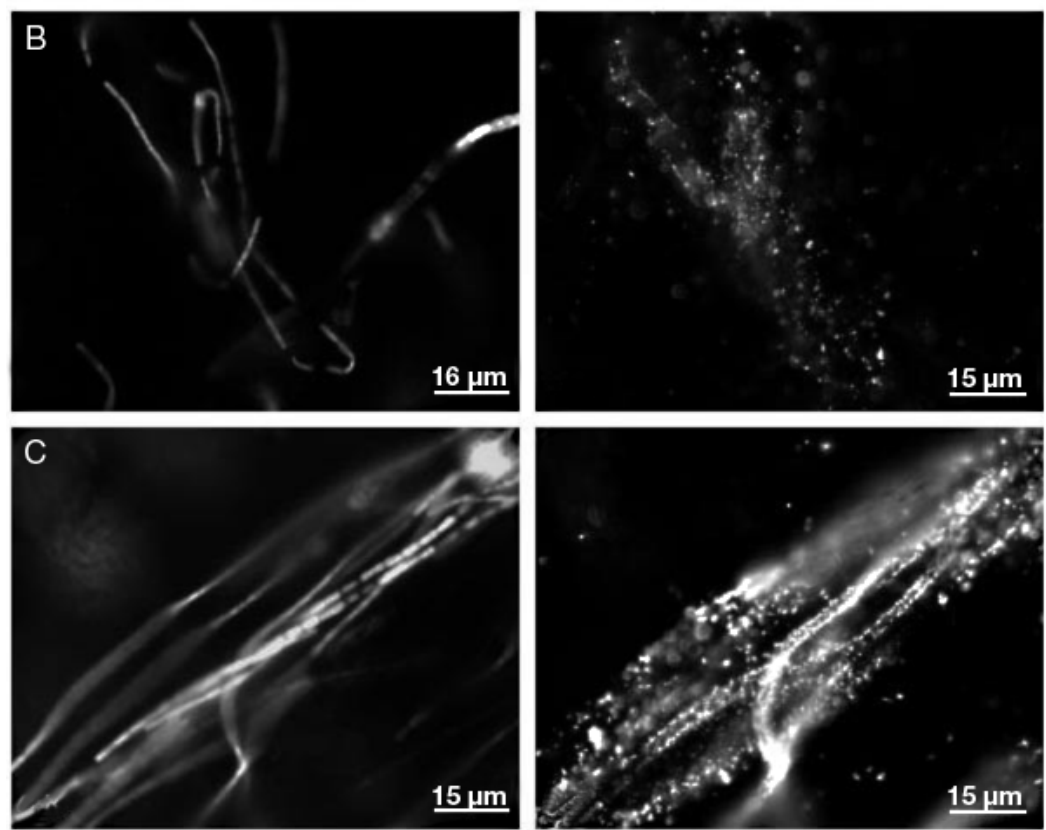

Fig. 6. Microphotographs of ELFA-labeled samples in both the red (chlorophyll autofluorescence) and green (ELFA fluorescence) channel. (A-C) Filamentous cyanobacteria Leptolyngbya spp. cells do not exhibit surface-bound phosphatase activity. Most of the active sites are distributed in the mucilaginous sheaths and activity is derived from associated bacteria

time. Espeland et al. (2002) reported that cell-bound bacterial phosphatase activity in biofilms is constitutive. The increase in free dissolved phosphatase may improve the flux of limited phosphorus supplies into the biofilm matrix by enhancing hydrolysis of organic phosphorus compounds that are not immediately available to surfacebound phosphatase (Espeland et al. 2002). This would enable cyanobacteria to benefit from bacterial phosphatase production without the need to produce their own enzyme, which suggests that the relationship between cyanobacteria and associated algae is indeed very close. With the abundant supply of EOC provided by intensive cyanobacterial photosynthesis, bacteria may be able to compete successfully for phosphorus with cyanobacteria (Jansson 1993). It would seem probable that, given the abundant EOC supply associated with cyanobacteria, the bacterial numbers would be higher in the cyanobacterial mat than in the underly-

Similar decreases in activity have been observed in other aquatic systems and are attributed to decreasing quality (content of refractory organics) of substrate and increasingly more anaerobic conditions in the lower layers of the sediment (Degobis et al. 1986, Newman \& Reddy 1992, Wright \& Reddy 2001). Arylsulphatase, on the other hand, was most active at layers of sediment 2.5 to $5.0 \mathrm{~cm}$ deep, perhaps favoring the more anaerobic conditions and experiencing lack of substrate at the upper layers.

Phosphatase was the only enzyme studied affected by $\mathrm{P}$ addition, significantly decreasing in activity at $\mathrm{P}$ and NP plots. This result supports the theory that these systems are P-limited. Wright \& Reddy (2001) observed similar trends for the activity of extracellular enzymes in Everglades wetland soils. Belizean alkaline wetlands do not appear to be limited by nitrogen, as nei- ing sediment. However, our results show no difference in bacterial counts between the upper sediment layers and the mat. This may be caused by the bacteria responding to increased photosynthesis with an increase in biomass rather than an increase in overall numbers (Espeland et al. 2001). Some studies have demonstrated increases in cell volumes relative to abundance in bacterial populations grown on UVexposed DOC (Lindell et al. 1995, 1996), and it is possible that bacterial cells in the mat sequester available carbon, thus generating greater individual mass (Espeland et al. 2001).

Microbial communities living in different sediments apparently use different strategies regarding phosphatase production. Bacteria in peat-based sediment showed predominantly surface-bound activity, whereas the majority of phosphatase activity appeared 


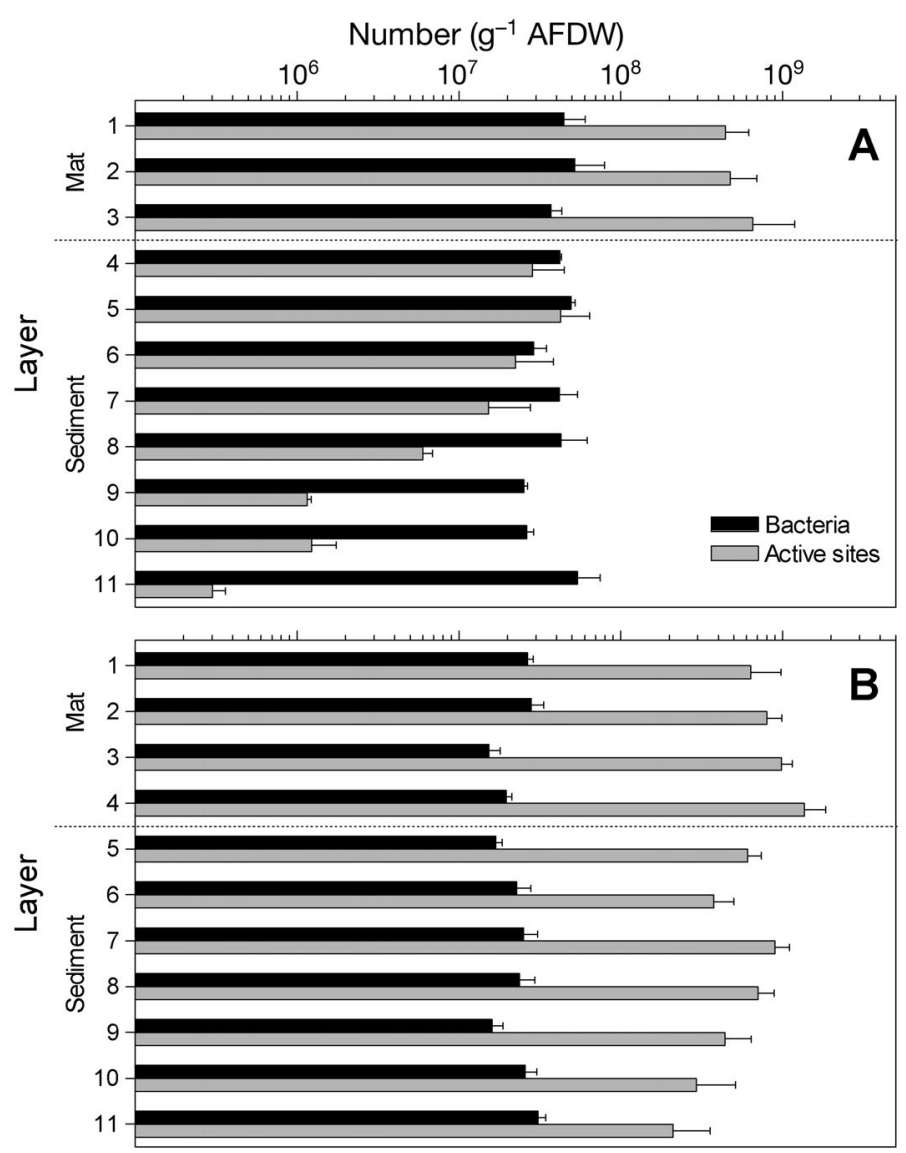

Fig. 7. Numbers of bacteria and active enzyme sites $\mathrm{g}^{-1}$ AFDW (logarithmic scale) in $1.5 \mathrm{~mm}$ thick layers of the cyanobacterial mat and the underlying sediment at: (A) the lowsalinity, peat-based location Frank and (B) high salinity marl-based location LB 11. (Error bars: + SE)

to be free in the marl-based sediment. As both cyanobacterial mats and marl sediments are rich in calcium carbonates, it is possible that free enzyme production in these microenvironments compensates for the reduced diffusibility of substrate caused by the adsorption of phosphorus to carbonates.

Acknowledgements. We thank P. Macek and J. Futrell for helping with sample collections and laboratory analyses. J. Lepš provided valuable comments concerning statistical testing. This research was supported partly by National Science Foundation grant NSF \# 0089211 and partly by Grant Agency of the Academy of Sciences of the Czech Republic grant \# A6017202.

\section{LITERATURE CITED}

Ainsworth AM, Goulder R (2000) Downstream change in leucine aminopeptidase activity and leucine assimilation by epilithic microbiota along the River Swale, northern England. Sci Total Environ 251-252:191-204
Alvarez S, Guerrero MC (2000) Enzymatic activities associated with decomposition of particulate organic matter in two shallow ponds. Soil Biol Biochem 32:1941-1951

Bell RT, Ahlgren GM, Ahlgren I (1983) Estimating bacterioplankton production by measuring ${ }^{3} \mathrm{H}$-thymidine incorporation in a eutrophic Swedish lake. Appl Environ Microbiol 45:1709-1721

Brock TD (1978) Thermophilic microorganisms and life at high temperatures. Springer-Verlag, New York

Castenholz RW (1973) Ecology of blue-green algae in hot springs. In: Carr NG, Whitton BA (eds) The biology of blue-green algae. Blackwell Scientific Publications, Oxford, p 379-414

Characklis WG, Marshall KC (1990) Biofilms: a basis for an interdisciplinary approach. In: Characklis WG, Marshall KC (eds) Biofilms. John Wiley \& Sons, New York, p 3-15

Chróst R J (1990) Microbial ectoenzymes in aquatic environments. In: Overbeck J, Chróst R J (eds) Aquatic microbial ecology: biochemical molecular appproaches. SpringerVerlag, New York, p 47-78

Degobis D, Homme-Maslowska E, Orio AA, Donazzolo R, Pavoni B (1986) The role of alkaline phosphatase in the sediments of Venice Lagoon on nutriet regeneration. Estuar Coast Shelf Sci 2:425-438

Downing JA, McClain M, Twilley R, Melack JM, Elser JJ, Rabalais NN (1999) The impact of accelerating land-use change on the N-cycle of tropical aquatic ecosystems: current conditions and projected changes. Biogeochemistry 46:109-148

Elasri MO, Miller RV (1999) Study of the response of a biofilm bacterial community to UV radiation. Appl Environ Microbiol 65:2025-2031

Espeland EM, Wetzel RG (2001a) Effects of photosynthesis on bacterial phosphatase production in biofilms. Microb Ecol 42:328-337

Espeland EM, Wetzel RG (2001b) Complexation, stabilization, and UV photolysis of extracellular and surface-bound glucosidase and alkaline-phosphatase: implications for biofilm microbiota. Microb Ecol 42:572-585

Espeland EM, Francoeur SN, Wetzel RG (2001) Influence of algal photosynthesis on biofilm bacterial production and associated glucosidase and xylosidase activities. Microb Ecol 42:524-530

Espeland EM, Francoeur SN, Wetzel RG (2002) Microbial phosphatase in biofilms: a comparison of whole community enzyme activity and individual bacterial cell-surface phosphatase expression. Arch Hydrobiol 153:581-593

Hartshorn GS (1988) Tropical and subtropical vegetation of Meso-America. In: Barbour MG, Billings WD (eds) North American terrestrial vegetation. Cambridge University Press, New York, p 215-236

Hoch B, Berger B, Kavka G, Herndl GJ (1996) Influence of wastewater treatment on the microbial ecology of a large, temperate river system - the Danube River. Hydrobiologia 321:205-218

Hoppe HG (1983) Significance of exoenzymatic activities in the ecology of brackish water: measurements by means of methylumbelliferyl substrates. Mar Ecol Prog Ser 11: 299-308

Hoppe HG (1993) Use of fluorogenic model substrates for extracellular enzyme activity (EEA) measurement of bacteria. In: Kemp PF (ed) Handbook of methods in aquatic microbial ecology. Lewis, Boca Raton, FL, p 423-431

Jansson M (1993) Uptake, exchange, and excretion of orthophosphate in phosphate-starved Scenedesmus quadricauda and Pseudomonas K7. Limnol Oceanogr 38: $1162-1178$ 
Jørgensen BB, Revsbech NP, Cohen Y (1983) Photosynthesis and structure of benthic microbial mats: microelectrode and SEM studies of four cyanobacterial communities. Limnol Oceanogr 28:1075-1093

Kim JG, Rejmánková E (2002) Recent history of sediment deposition in marl- and sand-based marshes of Belize, Central America. Catena 48:267-291

King RB, Baillie IC, Abell, TMB, Dunsmore, and 5 others (1992) Land resources assessment of northern Belize. Nat Resour Inst Bull 43: p 513

Komárek J (1989) Studies on the cyanophytes of Cuba 7-9. Folia Geobot Phytotaxon 24:171-206

Komárek J (1995) Studies on the cyanophytes (cyanoprokaryotes) of Cuba 10. New and little known chroococcalean species. Folia Geobot Phytotaxon 30:81-90

Lindell MJ, Graneli HW, Tranvik LJ (1995) Enhanced bacterial growth in response to photochemical transformation of dissolved humic matter. Limnol Oceanogr 40:195-199

Lindell MJ, Graneli HW, Tranvik LJ (1996) Effects of sunlight on bacterial growth in lakes of different humic content. Aquat Microb Ecol 11:135-141

Lock MA, Wallace RR, Costerton JW, Ventullo RM, Charlton SE (1984) River epilithon: toward a structural-functional model. Oikos 42:10-22

McNamara AM, Hill WR (2000) UV-B irradiance gradients affects photosynthesis and pigments but not food duality of periphyton. Freshw Biol 43:649-662

Nedoma J, Štrojsová A, Vrba J, Komárková J, Šimek K (2003) Extracellular phosphatase activity of natural plankton studied with ELF97 phosphate: fluorescence quantification and labeling kinetics. Environ Microbiol 5:462-472

Newman S, Reddy KR (1992) The role of sediment resuspension on alkaline phosphatase activity. Hydrobiologia 245:75-86

Paerl HW (1982) Interactions with bacteria. In: Carr NG, Whitton BA (eds). The biology of Cyanobacteria. University of California Press, Los Angeles, CA, p 449

Perez-Mateos M, Busto MD, Rad JC (1991) Stability and properties of alkaline phosphatase immobilized by soil particles. J Sc Food Agr 55:229-240

Porter KG, Feig YS (1980) The use of DAPI for identifying and counting aquatic microflora. Limnol Oceanogr 25:943-948

Rejmánková E, Komárková J (2000) Function of cyanobacterial mats in phosphorus-limited tropical wetlands. Hydrobiologia 431:135-153

Editorial responsibility: Gerhard Herndl, Texel, The Netherlands
Rejmánková E, Roberts DR, Pawley A, Manguin S, Polanco J (1995) Predictions of adult Anopheles albimanus densities in villages based on distance to remotely sensed larval habitats. Am J Trop Med Hyg 53:482-488

Rejmánková E, Pope KO, Post R, Maltby E (1996) Herbaceous wetlands of the Yucatan peninsula: communities at extreme ends of environmental gradients. Int Rev Gesamte Hydrobiol 81:233-252

Rejmánková E, Komárek J, Komárková J (2004) Cyanobacteria - a neglected component of biodiversity: patterns of species diversity in inland marshes of northern Belize (Central America). Divers Distrib 10: 189-199

Romaní AM, Marxsen J (2002) Extracellular enzymatic activities in epilithic biofilms of the Breitenbach: microhabitat differences. Arch Hydrobiol 155:541-555

Sinsabaugh RL, Linkins AE (1988) Exoenzyme activity associated with lotic epilithon. Freshw Biol 20:249-261

Sinsabaugh RL, Report D, Weiland T, Golladay SW, Linkins AE (1991) Exoenzyme accumulation in epilithic biofilms. Hydrobiologia 222:29-37

Stal LJ (2001) Coastal microbial mats: the physiology of a small-scale ecosystem. S Afr J Bot 67:399-410

Štrojsová A, Vrba J, Nedoma J, Komárková J, Znachor P (2003) Seasonal study of extracellular phosphatase expression in the phytoplankton of a eutrophic reservoir. Eur J Phycol 38:295-306

Thurman EM (1985) Organic geochemistry of natural waters. Nijhoff/Junk Publishers, Dordrecht

Van Loosdrecht MC, Lyklema J, Norde W, Zehnder AJB (1990) Influence of interfaces on microbial activity. Microbiol Rev 54:75-87

Vaitomaa J, Repka S, Saari L, Tallberg P, Horppila J, Sivonen K (2002) Aminopeptidase and phosphatase activities in basins of Lake Hiidenvesi dominated by cyanobacteria and in laboratory grown Anabaena. Freshw Biol 47: $1582-1593$

Wetzel RG (1991) Extracellular enzymatic interactions: storage, redistribution, and interspecific competition. In: Chróst RJ (ed) Microbial enzymes in aquatic environments. Springer-Verlag, New York, p 6-28

Wright AL, Reddy KR (2001) Phosphorus loading effects on extracellular enzyme activity in Everglades wetland soil. Soil Sci Soc Am J 65:588-595

Submitted: June 2, 2005; Accepted: January 4, 2006 Proofs received from author(s): July 31, 2006 